\title{
Rediscovery of Cameroon Dolphin, the Gulf of Guinea Population of Sousa teuszii (Kükenthal, 1892)
}

\author{
Isidore Ayissi, ${ }^{1,2,3}$ Gabriel Hoinsoudé Segniagbeto, ${ }^{4}$ and Koen Van Waerebeek ${ }^{5,6,7}$ \\ ${ }^{1}$ Association Camerounaise de Biologie Marine (ACBM), BP 52, Ayos, Cameroon \\ ${ }^{2}$ CERECOMA, Specialized Research Center for Marine Ecosystems, c/o Institute of Agricultural Research for Development, \\ P.O. Box 219, Kribi, Cameroon \\ ${ }^{3}$ Institute of Fisheries and Aquatic Sciences (ISH) at Yabassi, University of Douala, P.O. Box 2701, Douala, Cameroon \\ ${ }^{4}$ Département de Zoologie et de Biologie Animale, Faculté des Sciences, Université de Lomé, Lomé, Togo \\ ${ }^{5}$ Conservation and Research of West African Aquatic Mammals (COREWAM), c/o Department of Marine and Fisheries Science, \\ University of Ghana, P.O. Box LG99, Legon, Ghana \\ ${ }^{6}$ COREWAM-Senegal, Musée de la Mer de Gorée, IFAN-CH.A.D, Université de Dakar, Dakar, Senegal \\ ${ }^{7}$ Peruvian Centre for Cetacean Research (CEPEC), Lima 20, Peru
}

Correspondence should be addressed to Koen Van Waerebeek; cepec@speedy.com.pe

Received 30 December 2013; Accepted 18 February 2014; Published 23 March 2014

Academic Editors: M. Cords, B. Crother, and P. V. Lindeman

Copyright (C) 2014 Isidore Ayissi et al. This is an open access article distributed under the Creative Commons Attribution License, which permits unrestricted use, distribution, and reproduction in any medium, provided the original work is properly cited.

Since the 1892 discovery of the Atlantic humpback dolphin Sousa teuszii (Delphinidae), a species endemic to coastal western Africa, from a skull collected in Cameroon, not a single record has been documented from the country or neighbouring countries. Increasing concern about the continued existence of the Gulf of Guinea population of S. teuszii or "Cameroon dolphin" prompted an exploratory survey in May 2011. Shore-based effort, on foot (30.52 km; $784 \mathrm{~min})$, yielded no observations. Small boat-based surveys $(259.1 \mathrm{~km} ; 1008 \mathrm{~min})$ resulted in a single documented sighting of ca. 10 (8-12) Cameroon dolphins in shallow water off an open sandy shore near Bouandjo in Cameroon's South Region. The combination of a low encounter rate of 3.86 individuals $(100 \mathrm{~km})^{-1}$ suggesting low abundance and evidence of both fisheries-caused mortality and of habitat encroachment raises concerns about the Cameroon dolphin's long-term conservation prospect. Our results add to indications concerning several other $S$. teuszii populations that the IUCN status designation of the species as "Vulnerable" may understate its threat level.

\section{Introduction}

Here we describe coastal survey effort implemented in Cameroon in an attempt to relocate the "Cameroon dolphin," that is, the Gulf of Guinea population of the Atlantic humpback dolphin Sousa teuszii (Kükenthal, 1892) [1]. This population has been "lost" to science since 1892 when German zoologist Willy Kükenthal described the new dolphin species Sotalia teuszii, later reassigned to the genus Sousa. The discovery was based on a single skull collected by the then head of plantations Mr. Eduard Tëusz at Man O'War Bay, near Douala, in Cameroon's Southeast Region. Although a second specimen was collected in 1925 in Senegal, it remained unrecognised till 1965 [2]. No other cases were documented for half a century and Cameroon remained the only known range state of $S$. teuszii, earning the species its vernacular name in several languages, for example, Cameroon (river) dolphin [3-6], Kamerun Delphin, Kamerun-Flussdelphin [6-8], and Dauphin du Cameroun [2, 6]. Finally, in 1943, a specimen was captured in a shark net off M'Bour, Senegal [9], while the first live individual was retrieved from a beach seine at Joal in 1956 [10]. Further S. teuszii records followed in western Africa, ranging from Dakhla Bay, Western Sahara, south to Angola $[2,11,12]$. As the species, after its discovery, was not reported again from Cameroon between 1892 and 2011, its historical link with the country faded and the species became known as the Atlantic humpback dolphin $[6,8]$.

Despite a bizarre mix-up of the Man O'War dolphin skull with a shark-scavenged carcass apparently of an African manatee (Trichechus senegalensis), considering that its head 
showed "paired nostrils" and its stomach contents were exclusively vegetarian $[1,13]$, there is no reason to doubt that the $S$. teuszii holotype skull shipped to Jena University originated from Cameroon. Uncertainty about a possible herbivorous dolphin persisted until Cadenat [10] found exclusive fish remains in the stomach of a freshly captured animal in Senegal.

An exhaustive review of the biology of S. teuszii [11, 12] proposed eight preliminary stocks based largely on distributional grounds, amongst which the "Cameroon Estuary Stock" of unknown status because supported only by the holotype skull [1]. The lack of dedicated survey effort was assumed to be the main reason for the absence of later records in Cameroon. However, when $S$. teuszii was not found in Ghana despite significant port monitoring and the documentation of hundreds of small odontocetes comprising at least 12 species, the possibility of local extirpation could no longer be ignored [14-16].

In 2011, increasing concern about S. teuszii's status in Cameroon prompted an exploratory survey in its coastal waters as reported below. At the same time it was considered crucial to document any anthropogenic threats to S. teuszii, in particular to verify whether dolphin captures occurred and whether an active market in cetacean bushmeat for human consumption has become established as it has in Ghana and Nigeria [15-17].

\section{Materials and Methods}

2.1. Study Area and Ecology. Cameroon's coastline stretches over $402 \mathrm{~km}$ from the mouth of the Akwayafe River $\left(\mathrm{N} 04^{\circ} 40^{\prime}\right)$ bordering Nigeria south to the mouth of the Ntem River (N02 $20^{\prime}$ ) bordering Rio Muni (Equatorial Guinea), between longitudes $\mathrm{E} 08^{\circ} 15^{\prime}$ and E09 $30^{\prime}$ (Figure 1). The wide continental shelf occupies ca. $10,600 \mathrm{~km}^{2}$. At Douala and Kribi-Campo the $200 \mathrm{~m}$ isobath lies some $40 \mathrm{~km}$ offshore while off the Rio del Rey basin, it lies up to $80 \mathrm{~km}$ offshore. Due to significant erosion, especially in Southwest Region, the estuaries and mangroves are characterised by high turbidity extending up to $30 \mathrm{~km}$ offshore from Bakassi and the estuaries of "Bouches du Cameroon" $[18,19]$.

Coastal surface waters (20-30 m layer) are warm $\left(>24^{\circ} \mathrm{C}\right)$ throughout the year [20]. Salinity is low due to high rainfall and a dense river network. Peak salinity reaches $20 \breve{G}$ at $15 \mathrm{~km}$ from Douala port in the dry season and less than $12 \%$ in the rainy season [21]. The effects of the semidiurnal tides with variable amplitudes $(0.3-3 \mathrm{~m})$ are felt in the estuarine complexes. Up to 1973, mangroves covered some $2700 \mathrm{~km}^{2}$ and despite much destruction still constitute a predominant feature on Cameroon's coast [22]. Mangrovelined, wide estuarine channels comprise a primary habitat for S. teuszii in Senegal, Gambia, and Guinea [2, 11, 23]. Coastal work in Senegal, Gabon, and Angola demonstrated that this obligate nearshore species can be visually surveyed from small boats and from shore [2, 24, 25]. Both methods were implemented in four areas of Cameroon (Table 1), 7 May-5 June, 2011: (i) Limbe-Idenau coast (Southwest Region; sandy coast and mangrove); Ambas Bay and environs of Bota

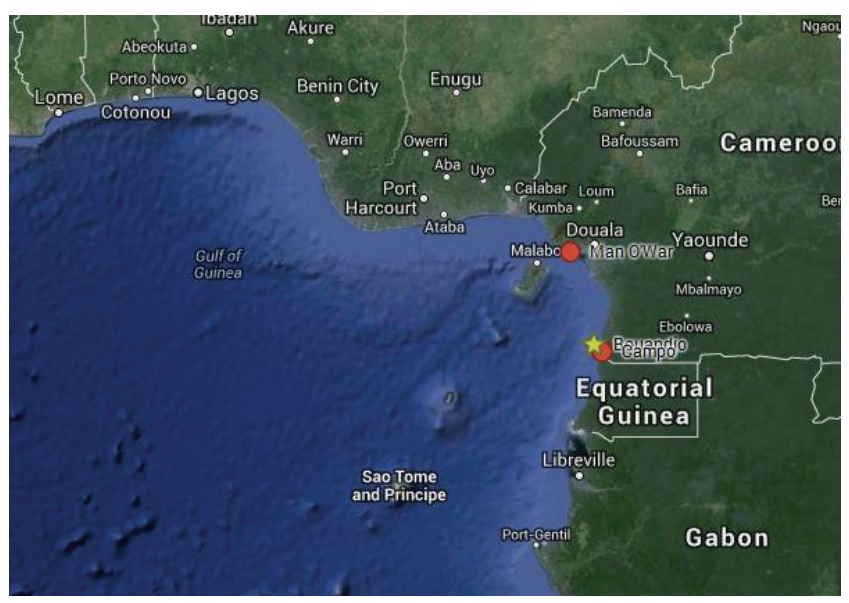

Figure 1: Coast of Cameroon as study area in the eastern Gulf of Guinea. Locations of three authenticated records of Cameroon dolphins Sousa teuszii are plotted: two specimens (red dots) including the 1892 holotype skull near Douala and a specimen captured at Campo in 2012; single sighting (yellow star) of ca. 10 free-ranging individuals at Bouandjo in 2011.

Islands; (ii) Douala-Edea Wildlife Reserve, southern shores of the Cameroon Estuary (Littoral Region, mangrove channels alternating with open sandy coast); (iii) area north of Ntem River estuary (South Region) bordering Equatorial Guinea; and (iv) Dibamba and Sanaga tidal rivers. The type locality, Man O'War Bay (N03.94839 ${ }^{\circ}$, E009.22416 $)$, occupied by a military garrison, was not accessible.

2.2. Survey Methods. In five days of small-boat surveys (Table 1), either from a $4 \mathrm{~m}$ dug-out canoe with a $8 \mathrm{hp}$ outboard engine or a $4.5 \mathrm{~m}$ fibreglass boat with a $40 \mathrm{hp}$ engine, three observers searched $180^{\circ}$ ahead mostly by naked eye. Visibility was good to excellent and Beaufort sea state ranged 0-2. Total boat-based survey effort covered $259.1 \mathrm{~km}$ over 1,008 $\mathrm{min}$. Shore-based effort (784 $\mathrm{min}$ ), on foot, covered $30.52 \mathrm{~km}$ of beaches, mainly north of the Ntem River. Two observers slowly walked along the high-water line alternately scanning the sea and inspecting flotsam for any skeletal remains washed ashore. At $10 \mathrm{~min}$ intervals inshore waters were scanned with $8 \times 40 \mathrm{~mm}$ binoculars. Distances were calculated with the odometer function of a hand-held GPS (Garmin Oregon 450t).

Several locals at 20 fish landing sites were casually queried regarding any recent cetacean bycatches or sightings [26]. In addition a structured interview, supported by photographs of expected cetaceans, was conducted of the first encountered fisherman at each site who gave coherent and detailed replies ( $n=17$ ), except at three locations where 3-4 persons were interviewed as a group and their consensus view was summarized. All 25 fishermen interviewed were asked about the presence of coastal cetaceans including Cameroon dolphin, common bottlenose dolphin Tursiops truncatus, and humpback whale Megaptera novaeangliae. 
TABLE 1: Details of visual survey effort for Cameroon dolphin on the coast of Cameroon, from 07 to 28 May, 2011.

\begin{tabular}{|c|c|c|c|c|}
\hline Date & Departure point & Destination (arrival time) & Effort & Comments \\
\hline \multicolumn{2}{|c|}{ Boat-based surveys } & \multicolumn{3}{|c|}{ Total: $259.1 \mathrm{~km}(1008 \mathrm{~min})$} \\
\hline $17 / 05 / 11$ & $\begin{array}{l}\text { Campo, N02 } 22.861^{\prime}, \mathrm{E}^{\circ} 9^{\circ} 49.465^{\prime} \\
(09: 25 \mathrm{~h})\end{array}$ & $\begin{array}{l}\text { Ebodjé, N02³4.550' }{ }^{\prime} \text { E09²49.497' } \\
(13: 00 \mathrm{~h})\end{array}$ & $\begin{array}{l}22.5 \mathrm{~km} \\
(215 \mathrm{~min})\end{array}$ & $\begin{array}{l}\text { Coastal strip Campo-Ebodjé. } 2 \\
\text { observers, small canoe, } 8 \mathrm{HP} \\
\text { outboard }\end{array}$ \\
\hline 21/05/11 & $\begin{array}{l}\text { Limbé, N04 } 00.012^{\prime}, \text { E09 }^{\circ} 12.551^{\prime} \\
(09: 40 \mathrm{~h})\end{array}$ & 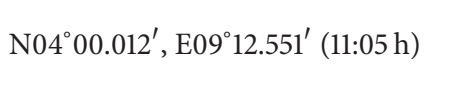 & $\begin{array}{l}20.2 \mathrm{~km} \\
(85 \mathrm{~min})\end{array}$ & $\begin{array}{l}\text { Limbé harbour and environs. } 2 \\
\text { observers, canoe, } 40 \mathrm{HP} \text { outboard }\end{array}$ \\
\hline $23 / 05 / 11$ & $\begin{array}{l}\text { Mouanko, } \mathrm{N}^{\circ} 33^{\circ} 38.371^{\prime}, \mathrm{E}^{\prime} 9^{\circ} 48.060^{\prime} \\
(14: 54)\end{array}$ & $\begin{array}{l}\text { Mbiako, } \mathrm{N}^{\circ} 3^{\circ} 35.317^{\prime}, \mathrm{E} 09^{\circ} 38.934^{\prime} \\
(16: 28)\end{array}$ & $\begin{array}{l}33.91 \mathrm{~km} \\
(94 \mathrm{~min})\end{array}$ & $\begin{array}{l}\text { Downriver Sanaga and short } \\
\text { estuary excursion; } 3 \text { observers, } \\
\text { fibreglass boat; } 40 \mathrm{HP} \text { outboard }\end{array}$ \\
\hline $24 / 05 / 11$ & $\begin{array}{l}\text { Mbiako, } \mathrm{N}^{\circ} 33^{\circ} 35.317^{\prime}, \mathrm{E} 09^{\circ} 38.934^{\prime} \\
(10: 30 \mathrm{~h})\end{array}$ & $\begin{array}{l}\text { Sitan, } \mathrm{N} 03^{\circ} 28.347^{\prime}, \mathrm{E} 09^{\circ} 44.183^{\prime} \text { and } \\
\text { return to Mbiako }(13: 14)\end{array}$ & $\begin{array}{l}42.56 \mathrm{~km} \\
(164 \mathrm{~min})\end{array}$ & $\begin{array}{l}100-200 \mathrm{~m} \text { off beach, return } \\
300-500 \mathrm{~m} \text { off beach; } 3 \text { observers, } \\
\text { fibreglass boat, } 40 \mathrm{HP}\end{array}$ \\
\hline $24 / 05 / 11$ & $\begin{array}{l}\text { Mbiako, } \mathrm{N}^{\circ} 33^{\circ} 35.317^{\prime}, \mathrm{E} 09^{\circ} 38.934^{\prime} \\
(14: 27)\end{array}$ & $\begin{array}{l}\text { Bolondo, } \mathrm{N}^{\circ} 3^{\circ} 48.731, \mathrm{E}^{\circ} 9^{\circ} 33.470^{\prime} \\
(16: 23 \mathrm{~h})\end{array}$ & $\begin{array}{l}35.65 \mathrm{~km} \\
(116 \mathrm{~min})\end{array}$ & $\begin{array}{l}150-300 \mathrm{~m} \text { off beach, } 3 \text { observers, } \\
\text { fibreglass boat, } 40 \mathrm{HP}\end{array}$ \\
\hline $25 / 05 / 11$ & $\begin{array}{l}\text { Bolondo, } \mathrm{N}^{\circ} 3^{\circ} 48.731, \mathrm{E} 09^{\circ} 33.470^{\prime} \\
(09: 15)\end{array}$ & $\begin{array}{l}\text { Manoka N03 } 52.004^{\prime}, \mathrm{E}^{\circ} 9^{\circ} 37.761^{\prime} \\
\left(12: 00 \text { h), penins.tip, } \mathrm{N}^{\circ} 49.273^{\prime}\right. \\
\mathrm{E}^{\circ} 9^{\circ} 32.711^{\prime}(14: 57)\end{array}$ & $\begin{array}{l}50.88 \mathrm{~km} \\
(201 \mathrm{~min})\end{array}$ & $\begin{array}{l}\text { Survey of main creeks and estuary, } 3 \\
\text { observers, fibreglass boat, } 40 \mathrm{HP}\end{array}$ \\
\hline $26 / 05 / 11$ & $\begin{array}{l}\text { Bolondo, } \mathrm{N}^{\circ} 3^{\circ} 48.731, \mathrm{E}^{\circ} 9^{\circ} 33.470^{\prime} \\
(11: 41 \mathrm{~h})\end{array}$ & $\begin{array}{l}\text { Mouanko, N03 } 38.371^{\prime}, \text { E}^{\circ} 9^{\circ} 48.060^{\prime} \\
(13: 54 \mathrm{~h})\end{array}$ & $\begin{array}{l}53.40 \mathrm{~km} \\
(133 \mathrm{~min})\end{array}$ & $\begin{array}{l}\text { Coastal strip; 13:03 h entering } \\
\text { Sanaga river and upriver survey. }\end{array}$ \\
\hline \multicolumn{2}{|c|}{ Beach-based surveys } & \multicolumn{3}{|c|}{ Total: $30.52 \mathrm{~km}(784 \mathrm{~min})$} \\
\hline $16 / 05 / 11$ & River Ntem mouth $(06: 00 \mathrm{~h})$ & $\begin{array}{l}\text { River Ntem estuary, right bank } \\
(07: 30 \mathrm{~h})\end{array}$ & $\begin{array}{c}0 \mathrm{~km} \\
(90 \mathrm{~min})\end{array}$ & 1 observer, stationary position \\
\hline $16 / 05 / 11$ & $\mathrm{~N} 02^{\circ} 21.104^{\prime}, \mathrm{E} 09^{\circ} 49.397^{\prime}(10: 20 \mathrm{~h})$ & 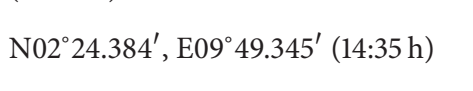 & $\begin{array}{l}6.45 \mathrm{~km} \\
(255 \mathrm{~min})\end{array}$ & 2 observers, on foot, NE direction \\
\hline $16 / 05 / 11$ & 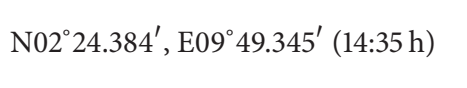 & 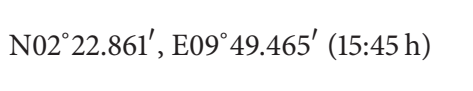 & $\begin{array}{l}2.95 \mathrm{~km} \\
(70 \mathrm{~min})\end{array}$ & 2, on foot, SW direction \\
\hline $17 / 05 / 11$ & $\mathrm{~N} 02^{\circ} 21.104^{\prime}, \mathrm{E} 09^{\circ} 49.397^{\prime}(07: 30 \mathrm{~h})$ & $\mathrm{N} 02^{\circ} 22.861^{\prime}, \mathrm{E} 09^{\circ} 49.465^{\prime}(08: 35 \mathrm{~h})$ & $\begin{array}{l}3.50 \mathrm{~km} \\
(65 \mathrm{~min})\end{array}$ & 2, on foot, NE direction, low tide \\
\hline $19 / 05 / 11$ & $\begin{array}{l}\text { Idenau, N04 } 13.045^{\prime}, \text { E0 } 8^{\circ} 59.133^{\prime} \\
(10: 25 \mathrm{~h})\end{array}$ & $\begin{array}{l}\mathrm{N} 04^{\circ} 13.629^{\prime}, \mathrm{E} 08^{\circ} 58.537^{\prime} \text { and return } \\
\text { to Idenau }(11: 55 \mathrm{~h})\end{array}$ & $\begin{array}{l}3.75 \mathrm{~km} \\
(90 \mathrm{~min})\end{array}$ & 3, on foot, NW/NE, rising tide \\
\hline 19/05/11 & $\begin{array}{l}\text { Seme, N04 } 03.358^{\prime}, \mathrm{E}^{\circ} 9^{\circ} 03.181^{\prime} \\
(15: 06 \mathrm{~h})\end{array}$ & $\begin{array}{l}\mathrm{N} 04^{\circ} 03.579^{\prime}, \mathrm{E}^{\prime} 9^{\circ} 02.726^{\prime} \text { and } \\
\text { return }\end{array}$ & $\begin{array}{l}2.22 \mathrm{~km} \\
(86 \mathrm{~min})\end{array}$ & 2, on foot, high tide \\
\hline $25 / 05 / 11$ & $\begin{array}{l}\text { Northern tip peninsula, } \\
\text { N03 }^{\circ} 49.273^{\prime}, \text { E}^{\circ} 32.711^{\prime}(15: 12 \mathrm{~h})\end{array}$ & $\begin{array}{l}\mathrm{N} 03^{\circ} 47.722^{\prime} \mathrm{E} 09^{\circ} 33.724^{\prime} \text { and return } \\
\text { to Bolondo, } \mathrm{N}^{\circ} 48.731 \text {, } \\
\mathrm{E}^{\circ} 9^{\circ} 33.470^{\prime}(18: 20)\end{array}$ & $\begin{array}{l}11.65 \mathrm{~km} \\
(128 \mathrm{~min})\end{array}$ & 2 , on foot \\
\hline
\end{tabular}

\section{Results and Discussion}

No dolphins were seen, nor remains found, during the shorebased effort. The boat-based surveys resulted in a single $S$. teuszii sighting on 17 May, 2011 (11:05 h GMT+01), the first ever sighting record in Cameroon (Figure 2). The encounter lasted for 10 min under optimal conditions, including excellent visibility and 1 Beaufort sea state. With a speed of $9 \mathrm{~km} \cdot \mathrm{hr}^{-1}$, the canoe's distance from the open sandy shore fluctuated from 250 to $500 \mathrm{~m}$ while avoiding sand banks and submerged rock formations. The somewhat dispersed group of ca. 10 Cameroon dolphins (low, 8; high, 12) was

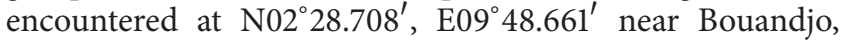
South Region. The group moved in turbid, shallow water, 250-600 $\mathrm{m}$ from the surf zone. The largest three individuals, evidently adults, presented a strongly developed dorsal hump. Smaller, juvenile specimens had a much fainter hump. Behavioural cues suggested foraging as individuals moved independently and rapidly with continuous changes in direction and speed, either subsurface or alternating with up to 4-5 min long dives. Aerial display was limited to a single full-body leap by one adult. Despite our unobtrusive approach, dolphins reacted with avoidance after just a few minutes, scattering in offshore direction, and moved out of sight $\mathrm{ca} .600 \mathrm{~m}$ from shore. The single sighting translating into a boat-based encounter rate of 0.386 sightings $(100 \mathrm{~km})^{-1}$ or 3.86 individuals $(100 \mathrm{~km})^{-1}$ suggests that the present abundance of $S$. teuszii in Cameroon may be very low.

Surveys of the Sanaga River on 23 and 26 May 2011 yielded no sightings (Figure 3). During 6 hrs on 3 and 4 June 2011, one of us (I. Ayissi) made small-boat surveys of the tidal Dibamba River but encountered no dolphins. This is in concordance with claims by local fisherfolk who deny the presence of dolphins in the Sanaga and Dibamba Rivers.

The original plan to survey the extensive northern mangrove channels including Rio-del-Rey was frustrated by Idenau port authorities denying permission for security reasons 


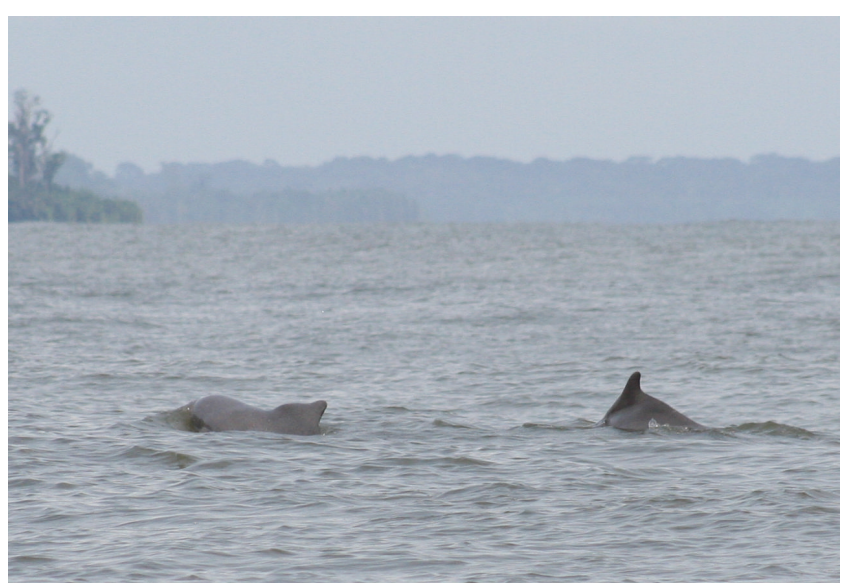

Figure 2: Two adult Cameroon dolphins Sousa teuszii, part of a small group of ca. 10 individuals foraging nearshore at Bouandjo, 17 May, 2011. This is the first authenticated sighting and the first evidence since 1892 of the presence of S. teuszii in Cameroon. Photo: K. Van Waerebeek.

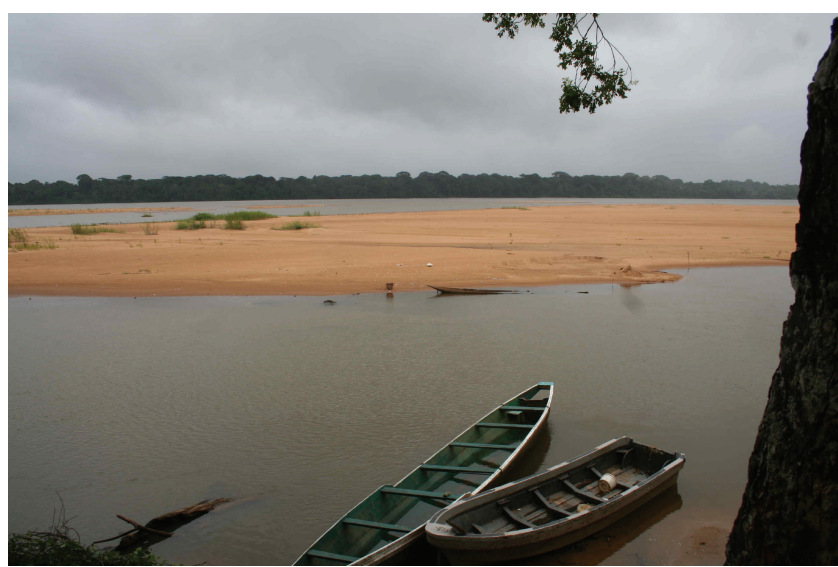

Figure 3: Despite its historical name "Cameroon River dolphin" implying potential riverine habitat, we encountered no dolphins in Cameroon's wide Sanaga River; their absence was confirmed by local fishermen. Photo: K. Van Waerebeek.

including piracy. Artisanal fishing effort and nearshore boat traffic were very intense near Idenau. Dozens of large canoes equipped with high-powered outboard engines transported merchandise and passengers to and from Nigeria. These noisy, high-speed crafts would almost certainly disturb and chase away any humpback dolphins, if present.

The only specimen evidence of $S$. teuszii in Cameroon (since 1892) consisted of a dolphin captured and landed by small-scale local fishermen on an indeterminate date

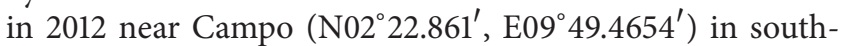
ern Cameroon (Figure 4). Although $81 \%$ of interviewed fishermen had seen dolphins from shore, none positively recognised S. teuszii from photographs, and $87.5 \%$ answered a resolute "never seen." In contrast, almost all fishermen recognised T. truncatus, a species not encountered during our surveys. However, a photo of a common bottlenose dolphin

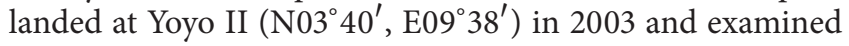

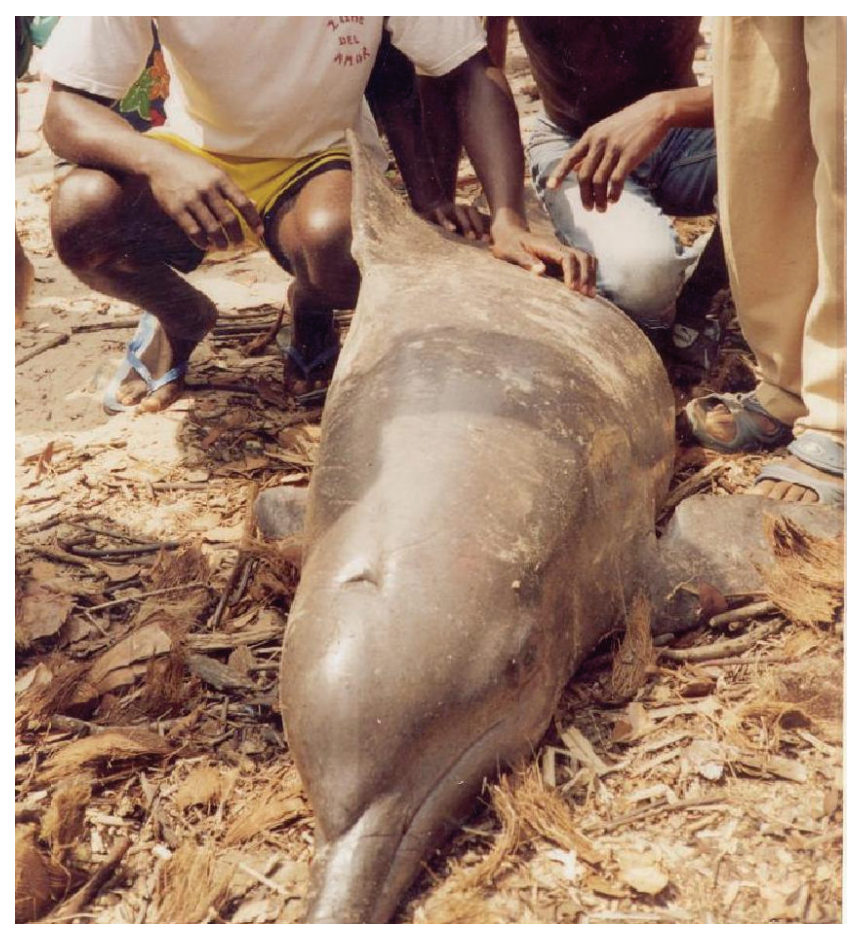

Figure 4: A Cameroon dolphin captured by artisanal fishermen near Campo, southern Cameroon, on an indeterminate date in 2012. Photo by unnamed fisherman from Campo.

by the authors confirmed the presence of $T$. truncatus in Cameroon.

So-called rapid gillnet bycatch assessments, based primarily on interviews with fishermen, indicated that cetacean bycatches occur but failed to obtain data on species and numbers $[27,28]$. The underperformance of interview surveys was consistent with our own findings [26] stressing the need for corroboration through direct monitoring of fisheries backed by specimen and photographic evidence. Besides S. teuszii and T. truncatus, photo evidence now exists for specimens killed in fisheries interactions of another four cetacean species in Cameroon, that is, humpback whale Megaptera novaeangliae, sperm whale Physeter macrocephalus, striped dolphin Stenella coeruleoalba, and a long-snouted form of common dolphin, Delphinus sp. [26].

\section{Conclusions}

After almost 120 years without humpback dolphin records in Cameroon, documentation of the unique Bouandjo sighting in 2011 and a single specimen captured at Campo in 2012 evidenced the continuing occurrence of Cameroon dolphins in the country. As new cases emerge in the Gulf of Guinea, the "Cameroon Estuary stock" (sensu van Waerebeek et al. [2]) may have a wider distribution and population structure will need revisiting. We suggest that a combined lack of surveys and marine mammalogists, low encounter rate, and small, inconspicuous group sizes are the primary reasons for the historical absence of $S$. teuszii records. Low abundance underscores the legitimacy of concern about 
long-term conservation of Cameroon dolphins. A similar situation was reported in Angola's Namibe province, where only 10 individuals were photo-identified despite extensive field effort $[12,25]$.

No dolphins were sighted in Cameroon's mangrove channels nor in the Sanaga and Dibamba rivers. While our effort was limited in scope, fishermen living along the river banks reported no dolphins in these rivers. Tidal currents may be very strong: $1-1.5 \mathrm{~m} / \mathrm{s}$ Influx and up to $2.6 \mathrm{~m} / \mathrm{s}$ for reflux [29]. Numerous sandbanks falling dry at low tide represent high stranding risk and may discourage humpback dolphins from venturing inside rivers. Nonetheless a final conclusion is premature.

Future surveying and photo-identification efforts should be expanded to cover all seasons and most of the coastline to obtain more robust density estimates. While economical and widely available, dug-out canoes can only offer low eye-height while surveying is restricted to Beaufort sea state 0-1 and low or no swell. The fibreglass boat offered a higher eye-height, faster speed, and superior functionality and stability.

The nearshore or estuarine habitat of S. teuszii magnifies its susceptibility to anthropogenic threats. Bycatch mortality in artisanal fisheries, prey depletion, disturbance, and cetacean bushmeat acquiring market value (fomenting direct captures) are of major concern. With increasing nearshore boat traffic, injurious or lethal collisions between fast craft and slow-swimming Atlantic humpback dolphins are an emerging threat, as documented for Chinese humpback dolphins Sousa chinensis in Hong Kong and Chinese waters [30, 31]. Not only does the boat avoidance behaviour of $S$. teuszii complicate surveying and photo-identification attempts [2, $8,25]$ but dense boat traffic may also lead to Cameroon dolphin communities abandoning home ranges in search of quieter, possibly poorer, feeding areas. Habitat encroachment from urban expansion, port and industrial construction, overfishing [32-34], chemical and acoustic pollution, and ghost nets [35] constitutes additional conservation problems. Scarcity of information on the fine-scale distribution and on stock structure, abundance, and ecology of the Cameroon dolphin prevents an efficient evaluation of the impact of threat factors and hinders efforts to raise public awareness $[2,8,11,25]$.

While the IUCN categorizes $S$. teuszii as "Vulnerable," the species is listed on CMS Appendix I/II as well as on CITES Appendix I. Most experts consider IUCN's "Vulnerable" classification to be an understatement of its true conservation status. Circumstantial evidence suggests that the species is already endangered in view of its low abundance throughout a fragmented range, unprecedented deterioration of its obligate shallow-water habitat, and significant fisheries-caused mortality coupled with an increased demand for marine bushmeat in western Africa $[2,8,25,36]$. To date, S. teuszii has not been reported in Ghana or Benin despite significant monitoring of cetacean landings $[2,16,37]$ suggesting the species has become very rare and perhaps even locally extinct. Equatorial Guinea and Nigeria are unconfirmed but highly probable range states, considering their extensive mangrovelined coast. Promotion of the historic significance of $S$. teuszii as a flagship species for Cameroon and the Gulf of
Guinea (the only aquatic mammal taxon first discovered in this region), underscored by its rediscovery, may help foster national awareness for the conservation of aquatic mammals in general. Even so, safeguarding a future for the iconic Cameroon dolphin will prove a formidable challenge and will depend on whether the implementation of proactive conservation measures, in particular installing nearshore marine protected areas, will succeed in the face of accelerating anthropogenic pressures. Inaction could result in the loss of one of Africa's most emblematic marine mammals.

\section{Conflict of Interests}

The authors declare that they have no conflict of interests regarding the publication of this paper.

\section{Acknowledgments}

Thanks are due to the many persons who facilitated or otherwise helped field work, particularly the D. O. of Mouanko and Campo, the senior staff from Ministry of Environment and Nature Protection including Dr. Ndongo Barthelémy (Inspector General N ${ }^{\circ}$ ), Dr. Wounissi (Director of Conservation), Mr. Djonou Roland and Mr. Pouth Jean Paul (Cooperation Unit), Mr. Beyiyi Gerard (SDPRN-CMS/Unit), Dr. Ngo Mpeck Marie Laure (National Coordinator GEFSmall Grants Programme), and Dr. Jean Folack (Chief of Station of Specialized Research Center of Marine Ecosystems). The authors thank also field staff from the Ministry of Livestock and Fisheries including Mr. Mouri, Mr. Abessolo, and Ms. Nking Gwendoline, the Chiefs Kema from Mbiako, Edimo from Suellaba, Ewandje from Yoyo I, and Moudjol Jean Bernard from Dibamba, as well as fishers Sebastien from Londji and Victor from Suellaba. Three anonymous reviewers provided useful comments that helped improve the paper. Field work was sponsored by the UNEP/CMS Convention for Migratory Species via a 2011 Small Grant and support received from the Colombus Zoo Conservation Fund, Ohio.

\section{References}

[1] W. Kükenthal, "Sotalia tëuszii n. sp., ein pflanzenfressender (?) Delphin aus Kamerun," Zoologische Jahrbücher Abteilung für Systematik, Ökologie und Geographie der Tiere, vol. 6, no. 3, pp. 442-446, 1892.

[2] K. Van Waerebeek, L. Barnett, A. Camara et al., "Distribution, status, and biology of the Atlantic Humpback Dolphin, Sousa teuszii (Kükenthal, 1892)," Aquatic Mammals, vol. 30, no. 1, pp. 56-83, 2004.

[3] W. F. J. Mörzer Bruyns, Field Guide of Whales and Dolphins, Uitgeverij Tor \& C.A. Mees, Amsterdam, The Netherlands, 1971.

[4] D. J. Coffey, D. K. Caldwell, and M. C. Caldwell, The Encyclopedia of Sea Mammals, Hart-Davis, MacGibbon, London, UK, 1977.

[5] M. Carwardine, Whales, Dolphins and Porpoises, Eyewitness Handbooks, Dorling Kindersley Limited, London, UK, 1995.

[6] B. M. Culik, Review of Small Cetaceans: Distribution, Behaviour, Migration and Threats, Regional Seas Reports and Studies, no. 177, UNEP/CMS, Bonn, Germany, 2004. 
[7] B. Grzimek, Grzimeks Tierleben, Enzyklopädie des Tierreiches, Kindler, Zürich, Switzerland, 1970.

[8] K. Van Waerebeek and W. F. Perrin, "Conservation status of the Atlantic humpback dolphin, a compromised future?" in Proceedings of the 14th Meeting CMS Scientific Council, Bonn, Germany, March 2007, Document CMS/ScC14/Doc.6.

[9] J. Cadenat, "Observations de cétacés au Sénégal," Notes Africaines, vol. 34, pp. 20-23, 1947.

[10] J. Cadenat, "Un delphinidae encore mal connu de la côte occidentale d'Afrique: Sotalia teuszii Kükenthal 1892," Bulletin de l'IFAN, vol. 18, pp. 555-566, 1956.

[11] K. Van Waerebeek, L. Barnett, A. Camara et al., "Conservation of cetaceans in the Gambia and Senegal 1999-2001, and status of the Atlantic humpback dolphin," WAFCET-2 Report, UNEP/CMS, Bonn, Germany, 2003.

[12] C. R. Weir, K. Van Waerebeek, T. A. Jefferson, and T. Collins, "West Africa's Atlantic humpback dolphin (Sousa teuszii): endemic, enigmatic and soon endangered?" African Zoology, vol. 46, no. 1, pp. 1-17, 2011.

[13] P.-J. van Beneden, "Un Cétacé fluviatile d’Afrique," Bulletin de l'Académie Royale des Sciences, des Lettres et des Beaux-Arts de Belgique, vol. 3, no. 23, pp. 350-355, 1892.

[14] P. K. Ofori-Danson, K. Van Waerebeek, and S. Debrah, "A survey for the conservation of dolphins in Ghanaian coastal waters," Journal of the Ghana Science Association, vol. 5, no. 2, pp. 45-54, 2003.

[15] K. Van Waerebeek, P. K. Ofori-Danson, and J. Debrah, "The cetaceans of Ghana, a validated faunal checklist," West African Journal of Applied Ecology, vol. 15, pp. 61-90, 2009.

[16] J. S. Debrah, P. K. Ofori-Danson, and K. Van Waerebeek, "An update on the catch composition and other aspects of cetacean exploitation in Ghana," IWC Scientific Committee Document SC/62/SM10, International Whaling Commission, Agadir, Morocco, 2010.

[17] M. Uwagbae and K. Van Waerebeek, "Initial evidence of dolphin takes in the Niger Delta region and a review of Nigerian cetaceans," Scientific Committee Document SC/62/SM1, International Whaling Commision, Agadir, Morocco, 2010.

[18] S. Morin and M. Kuete, "Le Littoral Camerounais: problèmes morphologiques," Travaux du Laboratoire de Géographie Physique Appliquée. Institut de Géographie, Université de Bordeaux III, vol. 11, pp. 5-53, 1989.

[19] J. A. Sayer, C. S. Harcourt, and N. M. Collins, Eds., The Conservation Atlas of Tropical Forest Africa, Macmillan Publishing Ltd., London, UK, 1992.

[20] A. Crosnier, "Fonds de pêche le long des côtes de la République Fédérale du Cameroun," Cahiers ORSTOM, pp. 1-133, 1964.

[21] L. R. Lafond, Etudes littorales et estuariennes en zone intertropicale humide [Thèse d'Etat en Sciences], Université de Paris, Paris, France, 1967.

[22] J. M. Kramkimel and B. Bousquet, Mangrove d'Afrique et de Madagascar: les mangroves du Cameroun, CEE, SECA, 1987.

[23] L. L. Bamy, K. Van Waerebeek, S. S. Bah et al., "Species occurrence of cetaceans in Guinea, including humpback whales with Southern Hemisphere seasonality," Marine Diversity Records, vol. 3, article e48, pp. 1-10, 2010.

[24] T. Collins, S. Ngouessono, and H. C. Rosenbaum, "A note on recent surveys for Atlantic humpback dolphins, Sousa teuszii (Kükenthal, 1892) in the coastal waters of Gabon," Scientific Committee Document SC/56/SM23, International Whaling Commission, 2004.
[25] C. R. Weir, "Distribution, behaviour and photo-identification of Atlantic humpback dolphins Sousa teuszii off Flamingos, Angola," African Journal of Marine Science, vol. 31, no. 3, pp. 319331, 2009.

[26] I. Ayissi, K. Van Waerebeek, and G. Segniagbeto, "Report on the exploratory survey of cetaceans and their status in Cameroon," in Proceedings of the 17th Meeting CMS Scientific Council, Bergen, Norway, November 2011, Document UNEP/CMS/ScC17/Inf.10.

[27] I. Ayissi, "Rapid gillnet bycatch survey of Cameroon," Tech. Rep., University of Yaoundé, Yaoundé, Cameroon, 2008.

[28] J. E. Moore, T. M. Cox, R. L. Lewison et al., "An interview-based approach to assess marine mammal and sea turtle captures in artisanal fisheries," Biological Conservation, vol. 143, no. 3, pp. 795-805, 2010.

[29] J. C. Olivry, "Fleuves et rivières du Cameroun. Collection monographies hydrologiques," ORSTOM Mémoires, vol. 9, pp. 1-733, 1986.

[30] T. A. Jefferson, S. K. Hung, and P. K. S. Lam, "Strandings, mortality and morbidity of Indo-Pacific humpback dolphins in Hong Kong, with emphasis on the role of organochlorine contaminants," Journal of Cetacean Research and Management, vol. 8, no. 2, pp. 181-193, 2006.

[31] K. Van Waerebeek, A. N. Baker, F. Félix et al., "Vessel collisions with small cetaceans worldwide and with large whales in the Southern Hemisphere, an initial assessment," Latin American Journal of Aquatic Mammals, vol. 6, no. 1, pp. 43-69, 2007.

[32] FAO, Marine Fisheries Resources of Cameroon: A Review of Exploited Fish Stocks, CECAF/ECAF Series, http://www.fao .org/docrep/003/S4639E/S4639E00.htm.

[33] FAO, "General situation of world fish stocks," http://www.fao .org/newsroom/common/ecg/1000505/en/stocks.pdf.

[34] J. Folack and O. Njifondjou, "Characteristics of marine artisanal fisheries in Cameroon," IDAF Newsletter, no. 28, pp. 18-21, 1995.

[35] G. Macfadyen, T. Huntington, and R. Cappell, Abandoned, Lost or Otherwise Discarded Fishing Gear, FAO Technical Paper, no. 523, Fisheries and Aquaculture, Rome, Italy, 2009.

[36] P. Clapham and K. Van Waerebeek, "Bushmeat and bycatch: the sum of the parts," Molecular Ecology, vol. 16, no. 13, pp. 26072609, 2007.

[37] Z. Sohou, J. Dossou-Bodjrenou, S. Tchibozo, F. Chabi-Yaouré, B. Sinsin, and K. Van Waerebeek, "Biodiversity and status of cetaceans in Benin, West Africa: an initial assessment," West African Journal of Applied Ecology, vol. 21, no. 1, pp. 121-134, 2013. 

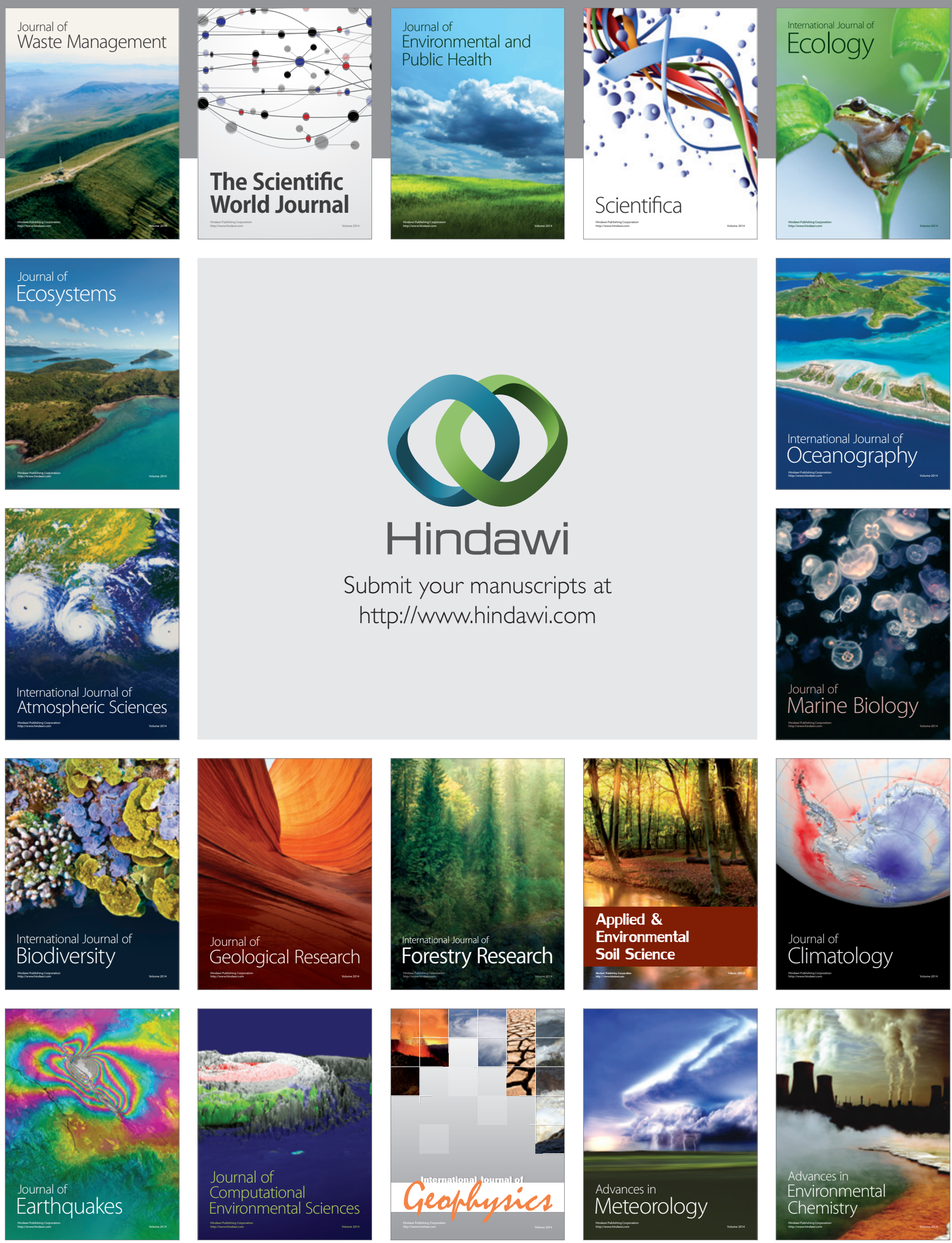